\title{
Different Rice based Cropping Systems can Influence Various Soil Organic Carbon Pools in a Clay Loam Soil of West Bengal
}

\author{
Swayambhu Ghosh ${ }^{1,2^{*}}$, Kalyan Chakrabarti ${ }^{1}$, \\ Aritra Kumar Mukherjee ${ }^{1,3}$ and Sudipta Tripathi ${ }^{1}$
}

\author{
${ }^{1}$ Agriculture Chemistry and Soil Science, Institute of Agricultural Sciences, \\ University of Calcutta, India \\ ${ }^{2}$ ICAR-Agricultural Technology Application Research Institute, Kolkata \\ ${ }^{3}$ Agriculture Chemistry and Soil Science, Bidhan Chandra Krishi \\ Viswavidyalaya, West Bengal, India
}

*Corresponding author

\begin{tabular}{|c|c|}
\hline & A B S T R A C T \\
\hline & \multirow{5}{*}{$\begin{array}{l}\text { Soil organic matter content and several fractions of soil organic carbon are considered to } \\
\text { be sensitive indicator of soil health who on several conditions like cropping choice and } \\
\text { management practices. The presence of different soil organic C pool in rice cultivating } \\
\text { soils are well documented but thoroughly studied information on relation between soil C } \\
\text { status and different rice based cropping managements are not available. Total organic C, } \\
\text { water extractable organic C, humus C, microbial biomass C and total carbohydrate } \\
\text { analyzed on the soils of long term cultivated rice fields for this study. Three rice based } \\
\text { cropping systems like rice-rice, rice-wheat, and rice-fallow from semi-arid climatic zone } \\
\text { of west Bengal were chosen for this purpose. After long term cultivation it was found, } \\
\text { soils may face 50-60\% depletion of TOC in cultivated soils than uncultivated virgin } \\
\text { grasslands. WEOC, MBC were considered as most sensitive parameter because of their } \\
\text { significant correlation with other parameters and capability of concluding on overall soil } \\
\text { health. Both the parameters showed rice-wheat (53\% and } 27 \% \text { higher than rice fallow } \\
\text { respectively) soil is much more biologically active than others. Total carbohydrate was } \\
\text { found higher in rice-rice ( } 80 \% \text { higher than rice fallow) and humus was found higher rice- } \\
\text { fallow ( } 76 \% \text { higher than rice rice) soils, reflecting differential impact on various C pools } \\
\text { by different management practice of rice. The correlation found between SOC pools were } \\
\text { mostly positive but with varying magnitude. Soil C pool dynamics after long term } \\
\text { cultivation affect not only justifies variable physicochemical and biochemical soil } \\
\text { properties but also gives a clue for choosing a suitable cropping pattern which may returns } \\
\text { with better soil health. }\end{array}$} \\
\hline $\begin{array}{l}\text { Organic carbon } \\
\text { fractions, Ratio } \\
\text { index value, Rice } \\
\text { based cropping } \\
\text { system, Soil health }\end{array}$ & \\
\hline Article Info & \\
\hline $\begin{array}{l}\text { Accepted: } \\
\text { 15 February } 2020 \\
\text { Available Online: } \\
10 \text { March } 2020\end{array}$ & \\
\hline & \\
\hline
\end{tabular}




\section{Introduction}

Monitoring quality of agricultural soils has become an integral part of farming nowadays. From very long time scientists were considering soil organic carbon (SOC) as a key attribute of soil fertility and productivity. It's immense potential to influence soil physico-chemical, and biochemical properties (Nieder and Benbi, 2008) made soil $\mathrm{C}$ as most important criteria for judging soil health. Because of its very sensitive nature, SOC may be affected by various anthropogenic or environmental factors. For example, sometimes organic matter storage in soil can be severely controlled by land use, as it explicitly controls type, frequency, and quantity of leaf or plant residue deposition as well as the process of humification (Shepherd et al., 2001).Soil organic matter is composed of several identifiable organic $\mathrm{C}$ fractions. Land use and soil management not only affects total amount of soil organic $\mathrm{C}$ but may also change the relative significance of the organic matter stabilization process. As a result of that, several constituent SOC fractions become vulnerable to land use effects.

There are several soil $\mathrm{C}$ fraction schemes available, but here the fractions varying in their liability and presence were estimated in chemical and biochemical techniques. Because chemical fractionations are seemed to be much easier and relatively faster for estimating how cropping systems affect SOC and its fractions. It was hypothesized to check the effects of cropping pattern on those fractions quantitatively. The labile SOC pool such as water-extractable organic $\mathrm{C}$ (WEOC) becomes affected by management practices much faster than total organic carbon (TOC) (Huang et al., 2008). Whereas, microbial biomass like active soil $\mathrm{C}$ pools behaves as very sensible indicator of SOC and biological activities for any kind of cropping management stress (Haynes, 2005). Most stable and largest pool of soil is humus which forms through several biochemical complex reactions in soil over a long period, and controls different soil properties. The humus formation process seems to be also affected by soil management like tillage. The carbohydrates coming from either plant residues or microbes in soil, shows a great impact on several soil processes like energy source of microbes or reaction component for humification process. Mitsuchi (2012) showed earlier that, effects like tillage process makes humus $\mathrm{C}$ as a changeable factor in soil. The observation of humus has a great importance for cropping effect especially when rice cultivation is considered. Along with total organic $\mathrm{C}$ or $\mathrm{SOC}$ fractions, $\mathrm{pH}$, CEC, nitrogen content sometimes shows susceptibility to the cropping pattern (Kumar and Goh, 1999) which has been found to be important in this study to assess cropping management induced effect on soil.

This study was designed to assess the effect of most common cultivation of West Bengal in India i.e. rice based cropping systems on soil with a special reference on soil organic $\mathrm{C}$ and its fractions. As described earlier, SOC represents a large reservoir and measurable changes in it are very slow to occur. Thus it is difficult to find out any short term effect of cropping system on SOC stock and its fractions. For this reason, three experimental plots were taken in this study, where specific type of cropping is being practiced from long time, against another uncultivated grassland plot which has been kept virgin till date.

Information on long term management induced changes of rice based system on soil $\mathrm{C}$ pools in semi-arid subtropics are limited in literatures. This study was aimed to gain information on that through the observations of some physicochemical and biochemical parameters of soils, cultivated under rice-rice, rice-wheat and rice-fallow cropping pattern. 


\section{Materials and Methods}

\section{Site description and soil collection}

Soils for the present study were collected from the agricultural farm of University of Calcutta at Baruipur, 24 paragana (South), West Bengal $\left(22.35^{\circ} \mathrm{N}, 88.44^{\circ} \mathrm{E}\right)$. The soils of the experimental site were characterized as Fluvaquent, olive green in color, and clay loam in texture. Surface soils (up to a depth of $15 \mathrm{~cm}$ ) were collected from 4 different land use types, namely rice-rice (RR), rice- wheat $(\mathrm{RW})$, rice-fallow (RF) and grassland (GL), for this study. A brief description and cropping history of the sampling sites is given in supplementary fig. 1. Five replicated soil samples from each plot were taken. The replicated soil samples were collected by taking sufficient amount of soil randomly from the field followed by mixing thoroughly during the 3rd week of January, 2018. Visible fauna, plant debris, stones, rubbles etc. were removed and the soils and were brought to the laboratory on the same day in properly sealed and labeled polythene packs. All the field moist soil samples were stored at $4^{\circ} \mathrm{C}$ prior to determination of microbial biomass carbon maintaining proper moisture content. A portion of the field moist soils were air dried. Before analysis, all samples were further homogenized by crushing and sieving $(<1 \mathrm{~mm})$. Physico-chemical parameters of the soil samples were determined with the air dried soils.

\section{Soil analysis}

\section{Physico-chemical properties}

From the initially air dried soil samples, soil texture (pipette method), $\mathrm{pH}$ (1:2.5 soil-water suspension), Total organic carbon (Walkley and Black, 1934), Total kjeldahl N (Kjeldhal method) and Cation exchange capacity (Bascomb, 1964) were determined. C/N ratio was calculated from the estimated TOC and TKN value. Rest of the dried soil samples were used for carbon fractions estimation.

\section{Fractions of organic carbon in soils}

\section{Microbial biomass carbon}

The freshly brought field moist soils were used for microbial biomass carbon (MBC) determination by ninhydrin-reactive nitrogen method (Jenkinson, 1994). Prior to estimation, the sieved soil was adjusted to $40 \%$ of its water holding capacity by spraying sterile distilled water when necessary and incubated in the dark for 7 days at $25^{\circ} \mathrm{C}$ for stabilizing microbial biomass. Two portions (10g each) of the moist soil were accurately weighed. One portion was immediately extracted with $2(\mathrm{M}) \mathrm{KCl}$ solution for 30 minutes in an oscillating shaker at 200 r.p.m. This was then filtered and the filtrate was stored at $-15^{\circ} \mathrm{C}$ for further determination of ninhydrin- reactive nitrogen. Another portion of the weighed soil was fumigated in vacuum desiccator under reduced pressure with alcohol-free chloroform. After fumigation, the soil was defumigated and then extracted with 2(M) $\mathrm{KCl}$ solution. The filtrate was preserved at $-15^{\circ} \mathrm{C}$ for further determination of ninhydrin- reactive nitrogen. Ninhydrinreactive nitrogen in the filtrates of fumigated and unfumigated soil was determined by treating $1 \mathrm{ml}$ of the filtrate with $0.5 \mathrm{ml}$ of ninhydrin reagent in a water bath for 25 minutes. This was then cooled to room temperature and then $9.5 \mathrm{ml}$ of ethanol-water was added and mixed thoroughly. The absorbance values were measured in a spectrophotometer at a wavelength of $570 \mathrm{~nm}$ with $\mathrm{KCl}$ solution as a blank. The ninhydrinreactive nitrogen per gram of oven dry soil was calculated from a calibration curve produced by different concentrations of Leucine- ninhydrin complex with the respective absorbance values. The difference 
between the ninhydrin- reactive nitrogen in fumigated and unfumigated soil were represented as the ninhydrin-reactive nitrogen of the microbial biomass of the soil samples.The ninhydrin-reactive nitrogen was converted to microbial biomass carbon following the method of Amato and Ladd, 1988. The MBC contents of the soils were also calculated as a percentage index called ratio index value (RIV) (Sparling, 1992) and expressed as, $\mathrm{RIV}=(\mathrm{MBC} / \mathrm{TOC}) \mathrm{X} 100 \%$.

\section{Water soluble organic carbon}

$10 \mathrm{~g}$ air dried soil was extracted with $40 \mathrm{~mL}$ distilled water by shaking for 30 minutes in a horizontal shaker. The extract was filtered through Whatman no.42 filter paper. Carbon in this extract was determined by the procedure of Vance et al., (1987). Briefly, 2 $\mathrm{mL}$ of $0.4(\mathrm{~N}) \mathrm{K}_{2} \mathrm{Cr}_{2} \mathrm{O}_{7}$ and $15 \mathrm{~mL}$ of acid mixture $\left(\mathrm{H}_{2} \mathrm{SO}_{4}: \mathrm{H}_{3} \mathrm{PO}_{4}:: 3: 2\right)$ were added to 8 $\mathrm{mL}$ of filtered extract in a $250 \mathrm{~mL}$ round bottom flask fitted with a Liebig condenser. The whole mixture was gently refluxed for 30 min, cooled and diluted with $25 \mathrm{~mL}$ distilled water, which was added through the condenser as a rinse. The residual dichromate was measured by back titration with $0.04(\mathrm{~N})$ ferrous ammonium sulphate using ferroin indicators. At the end point, a sharp color change from green to buff pink took place. The carbon was estimated and expressed as $\mu \mathrm{g} \mathrm{g}^{-1}$ soil.

\section{Total soil carbohydrate content}

Carbohydrate content of the soils were determined by phenol-sulphuric acid method (Šafař́k and Šantrůčková (1992). $1 \mathrm{~mL}$ of aqueous soil extract and $1 \mathrm{~mL}$ of $5 \%$ phenol solution were mixed in a hard glass test tube. Immediately after mixing $5 \mathrm{~mL}$ of concentrated sulphuric acid was added to the mixture. The content of the test tube was vortexed for 10 seconds and allowed to stand at room temperature for one hour. The test tubes were centrifuged for 10 minutes at 4600 rpm. The absorbance of the colored samples was measured in spectrophotometer at 485 $\mathrm{nm}$ against phenol solution as blank. Results were computed with the help of a standard curve prepared with different concentrations of pure $\mathrm{D}$-glucose.

\section{Extractable humus carbon}

$5 \mathrm{~g}$ air dried soil was extracted with $100 \mathrm{~mL}$ freshly prepared Sodium pyrophosphate $\mathrm{NaOH}$ mixture by standing the mixture overnight. The extract was filtered through dry filter paper. $10 \mathrm{~mL}$ of this extract was neutralized by drop wise addition of $\mathrm{H}_{2} \mathrm{SO}_{4}$ till slight cloudiness. $10 \mathrm{~mL}$ of $0.4(\mathrm{~N})$ $\mathrm{K}_{2} \mathrm{Cr}_{2} \mathrm{O}_{7}$ and $20 \mathrm{~mL}$ conc. $\mathrm{H}_{2} \mathrm{SO}_{4}$ were added to the extracted material and heated the mixture to boiling for 5 minutes. After cooling, $30 \mathrm{~mL}$ distilled water was added as a rinse. The unused dichromate was titrated with $0.2 \mathrm{~N}$ Mohr salt solution with ferroin as indicator. From the back titration readings, carbon content was calculated (Kononova, 1966) and expressed in terms of $\mathrm{g} \mathrm{Kg}^{-1}$ soil.

\section{Statistics}

Assigning the soil as treatment factor, analysis of variance (ANOVA) was carried out by Completely Randomized Design (CRD) using IBM SPSS 11.0 statistical package. The factor soil had four levels and the replicate had five levels. The least Significant Difference (LSD) test was applied to evaluate the significance of differences between individual treatment factors. Where significant differences were found $(\mathrm{P} \leq 0.05)$ post-hoc analysis was conducted using Tukey's HSD test. To check the relationship between several C pools, 'Pearson's bivariate linear correlation' was done among the carbon fractions. Correlation matrix was formed depending on the correlation coefficient values. 


\section{Results and Discussion}

\section{Variation in physico-chemical properties}

Soils of RR and RW were found to be less acidic than either RF or GL, significant $(\mathrm{F}=846.033, \mathrm{P}<0.001)$ variation was observed between the $\mathrm{pH}$ of soils (Table 1). Cation exchange capacity of the soils was also found to be varied between the soils. Grassland soil showed significantly $(\mathrm{F}=11.582, \quad \mathrm{P}<0.001)$ higher CEC than that of all other soils. RF soil was found to show greater CEC than other two rice cropping systems. In case of TKN, Rice-Fallow soils were found to have lesser content than RR and RW but it was not significant. GL was found to be highest in TKN content significantly $(\mathrm{F}=29.112$, $\mathrm{P}<0.001)$.

TOC of the soils were observed to have a wide range of variation among the soils (Fig 1a). Grassland soils had significantly $(\mathrm{F}=567.625, \mathrm{P}<0.001)$ greater TOC than rice cropped soils. The RR soil had shown higher TOC than RW $(\mathrm{F}=567.625, \mathrm{P}=0.003)$ and $\mathrm{RF}$ $(\mathrm{F}=567.625, \mathrm{P}<0.001)$ though $\mathrm{RW}$ was not significantly different from RF in terms of TOC content. C/N ratio (Fig 1b) of the soils were not able to show any significant difference among them.

\section{Distribution of the carbon fractions in different cropping systems}

All the organic carbon fractions were observed to be varied significantly within the cropping systems. MBC of GL was found to be significantly highest $(\mathrm{F}=280.467$, $\mathrm{P}<0.001$ ) than that of other soils (Fig 1c). RR soils were different from RW ( $F=280.467$, $\mathrm{P}=0.045)$ but had no significant difference $(\mathrm{F}=280.467, \mathrm{P}=0.744)$ with $\mathrm{RF}$ soils, whereas $\mathrm{RF}$ soils were significantly lower $(\mathrm{F}=$ 280.467, $\mathrm{P}=0.006)$ than $\mathrm{RW}$ soils in terms of microbial biomass C. Ratio index value (RIV) was found be following the trend of MBC for rice based cropping systems. RR and RF were statistically at par $(\mathrm{F}=21.6, \mathrm{P}=0.237)$ in terms of RIV, soils of RW and GL were also statistically not different $(\mathrm{F}=21.6, \mathrm{P}=0.891)$. Though RW soils showed higher RIV than RR $(\mathrm{F}=21.6, \quad \mathrm{P}<0.001)$ and $\mathrm{RF} \quad(\mathrm{F}=21.6$, $\mathrm{P}=0.004)$ significantly.

GL soils in water extractable organic carbon (WEOC) fractions were statistically at per with that of $\mathrm{RW}$ soils $(\mathrm{F}=101.035, \mathrm{P}=0.484)$, RW soils were also indifferent with RR soils $(\mathrm{F}=101.035, \mathrm{P}=0.514)$. Though, $\mathrm{RF}$ soils were significantly lower than all other soils $(\mathrm{F}=101.035, \quad \mathrm{P}<0.001)(\mathrm{Fig} \quad 2 \mathrm{a}) . \quad$ The carbohydrate content was ranged from $17203.2 \pm 575.7 \mu \mathrm{g}$ D-glucose $\mathrm{g}^{-1}$ soil of GL to $1608.2 \pm 43.62 \mu \mathrm{g}$ D-glucose $\mathrm{g}^{-1}$ soil in RF (Fig 2b). In this range of variation all the cropping systems were found to be significantly different from each other $(\mathrm{F}=$ 1494.85, P<0.001). GL soils were found to have humus $\mathrm{C}$ few folds higher than that of rice cropping soils $(\mathrm{F}=1353.293, \mathrm{P}<0.001)$. $\mathrm{RF}$ soils were significantly higher in extractable humus $\mathrm{C}$ than that of RR or RW $(\mathrm{F}=1353.293, \mathrm{P}<0.001)$ soils. Within $\mathrm{RR}$ and RW soils, the prior one had lower humus $\mathrm{C}$ content significantly $(\mathrm{F}=1353.293, \mathrm{P}=0.001)$ (Fig 2c).

\section{Correlation between the carbon fractions}

Different soil C pools showed different kind and aptitude of correlation between them as well as with soil $\mathrm{p}^{\mathrm{H}}$ (Fig. 3). Total organic $\mathrm{C}$ $(\mathrm{r}=-0.795, \quad \mathrm{P}<0.001)$ and $\mathrm{MBC}(\mathrm{r}=-0.756$, $\mathrm{P}<0.001)$ showed significant negative correlation with $\mathrm{p}^{\mathrm{H}}$, though strong correlation was found by humus $\mathrm{C}(\mathrm{r}=-0.954, \mathrm{p}<0.001)$ with $\mathrm{pH}$. TOC and MBC was significantly correlated positively $(\mathrm{r}=0.961, \mathrm{P}<0.001)$, other $\mathrm{C}$ fractions like humuc $\mathrm{C}$, total carbohydrate and WEOC were also positively and significantly correlated with TOC. RIV being 
a function of TOC and MBC showed significant positive correlation with them, but it also had positive correlation with humus $\mathrm{C}$ $(\mathrm{r}=0.478, \mathrm{P}=0.033)$ and WEOC $(\mathrm{r}=0.462$, $\mathrm{P}=0.04)$. Apart from TOC, MBC had good significant correlation with other $\mathrm{C}$ fractions namely humus $\mathrm{C}(\mathrm{r}=0.817, \mathrm{P}<0.001)$, total carbohydrate $(\mathrm{r}=0.903, \mathrm{P}<0.001)$, WEOC $(\mathrm{r}=0.545, \mathrm{P}=0.013)$. Total carbohydrate was found to be significantly correlated with humus $\mathrm{C}(\mathrm{r}=0.603, \mathrm{P}=0.005)$ and WEOC $(\mathrm{r}=0.710, \mathrm{P}<0.001)$.

In this study, soil environmental factors such as $\mathrm{pH}$, organic matter, and nitrogen have been found to be affected by the cropping pattern. Again, several microbiological and biochemical factors are known to be directly or indirectly dependent on soil conditions. In this study the soil properties have appeared with a deep relationship with different amount of carbon pools. Thus differential physicochemical and biochemical properties between the soils of different cropping systems can be highlighted with the varying management practices like tillage, puddling, as well as crop specificity, crop rotation etc. From an objective viewpoint of searching for impacts of different land use systems on soil health, organic $\mathrm{C}$ found to be one of the most important indicator. Vaccari et al., 2012 referred in agro-ecosystems, land use change and the associated management practices exert a strong impact on soil organic carbon. Grassland soils are basically the rhizosphere soil, due to the enormous root system of the crop. The highest amount of soil organic carbon in grassland soil may be related to the root mass as well as the rhizo deposition of the enormous root system. The higher amount of organic carbon in rice-rice and rice-wheat soil compared to rice-fallow soil may be explained as effect of combined application of organic matter and fertilizers (Bell et. al., 2003). Compared to grassland soil the cultivated soils (RR, RW and RF) were less in organic carbon content, possibly due to cultural operations adopted for cultivation. The lowest organic carbon content of the ricefallow soil is due to loss of carbon during the fallow periods with no plant inputs (Becker and Johnson, 2001). The amount of organic matter in soils was also affecting TKN, because one large portion of soil nitrogen is found to be in organic form. Soils having lesser organic matter like $\mathrm{RR}$ and $\mathrm{RW}$ appeared with lesser TKN for the same reason.

Table.1 Table 1: Variation in several physico-chemical properties of soil due to different rice based cropping systems. Data represented in Mean $\pm \mathrm{SD}(\mathrm{n}=5)$ form and figures denoted by same alphabets are statistically similar at $5 \%$ probability level by DMRT

\begin{tabular}{l|lll}
\hline Cropping system & $\mathrm{pH}(1: 2.5 \mathrm{w} / \mathrm{v})$ & CEC $\left(\mathrm{cmol} \mathrm{p}^{+} \mathrm{Kg}^{1}\right)$ & TKN $\left(\mathrm{g} \mathrm{Kg}^{1}\right)$ \\
Rice-Rice (RR) & $6.086 \pm 0.02^{\mathrm{a}}$ & $17.86 \pm 0.76^{\mathrm{a}}$ & $1.45 \pm 0.22^{\mathrm{a}}$ \\
Rice-Wheat (RW) & $6.348 \pm 0.02^{\mathrm{b}}$ & $18.61 \pm 0.78^{\mathrm{a}}$ & $1.39 \pm 0.28^{\mathrm{a}}$ \\
& & $18.92 \pm 1.67^{\mathrm{a}}$ & $1.15 \pm 0.1^{\mathrm{a}}$ \\
Rice-Fallow (RF) & $5.66 \pm 0.05^{\mathrm{c}}$ & $23.274 \pm 2.5^{\mathrm{b}}$ & $2.27 \pm 0.14^{\mathrm{b}}$ \\
Grassland (GL) & $5.152 \pm 0.04^{\mathrm{d}}$ & & \\
\hline
\end{tabular}


Fig.1 Differences in (a) Organic Carbon, $(b) \mathrm{C} / \mathrm{N}$ ratio, $(c)$ Microbial biomass carbon, $(d)$ Ratio index value among Rice-Rice (RR), Rice-Wheat (RW), Rice-Fallow (RF) and Grassland (GL) cropping systems. Figures denoted by same alphabets are statistically similar at $\mathrm{P} \leq 0.05$ level

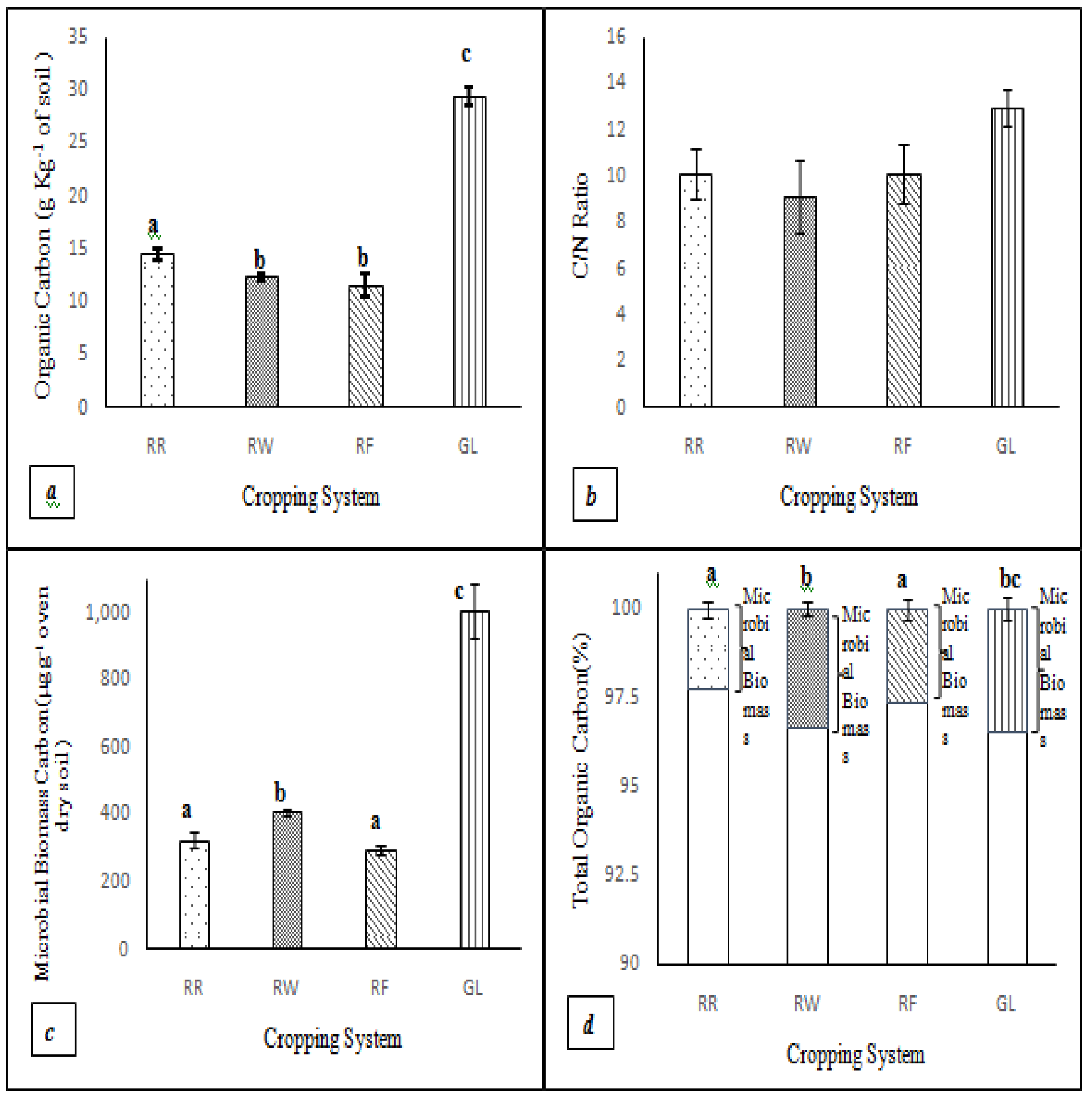


Fig.2 Variation in (a) Water Extractable Organic Carbon, (b) Total Carbohydrates (c) Extractable Humus Carbon among Rice-Rice (RR), Rice-Wheat (RW), Rice-Fallow (RF) and Grassland (GL) cropping systems. Figures denoted by same alphabets are statistically similar at $\mathrm{P} \leq 0.05$
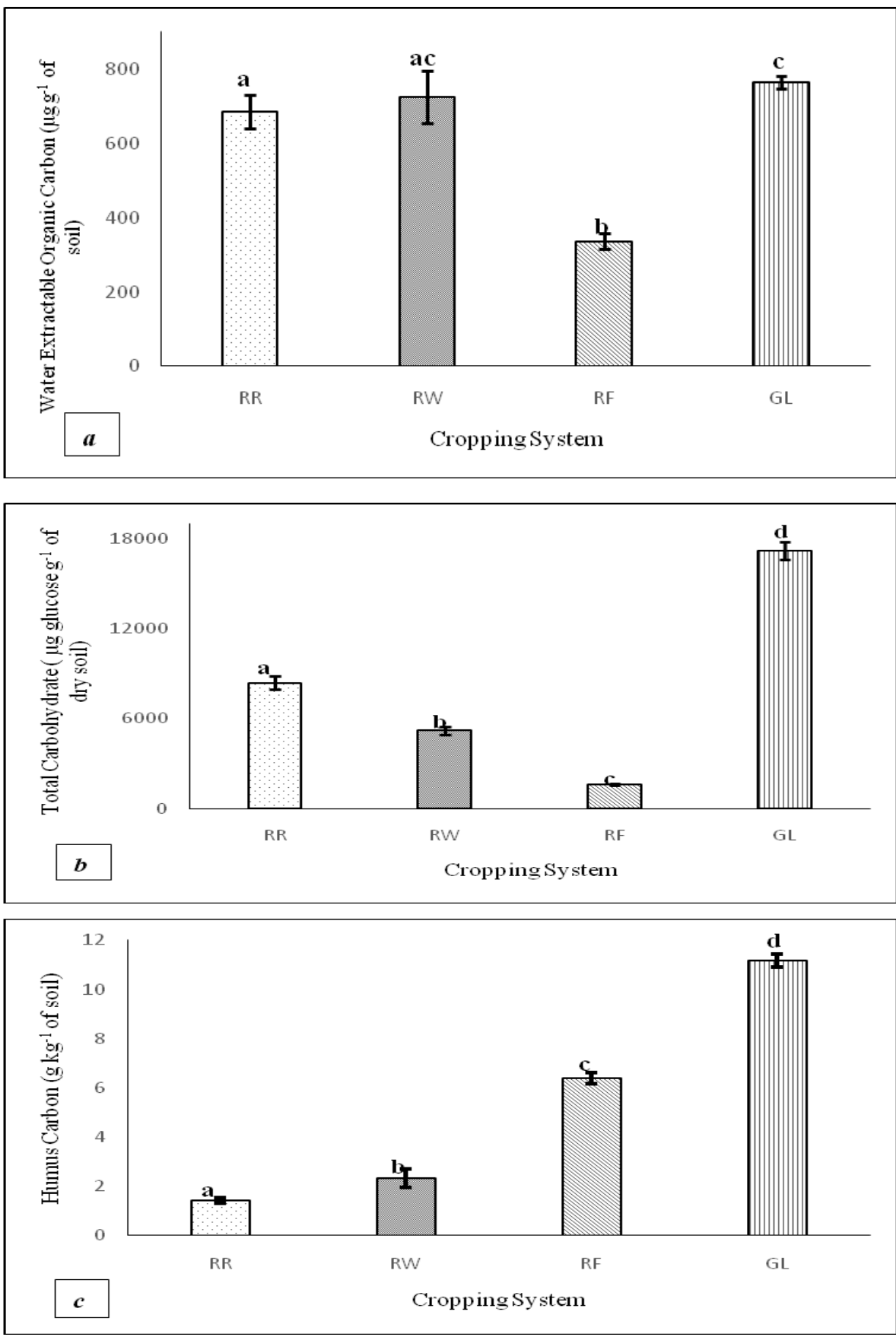
Fig.3 Correlation matrix (using hierarchical clustering) of the soil parameters. Colour chart gradient represented in right side of the matrix denotes Pearson's linear correlation coefficient (r). The correlation was done between RIV (ratio index value), MBC (microbial biomass C), TOC (total organic C), Carbohy (total carbohydrate), Humus (extractable humus C), WEOC (water extractable organic $\mathrm{C}$ ) and $\mathrm{pH}($ soil $\mathrm{pH})$

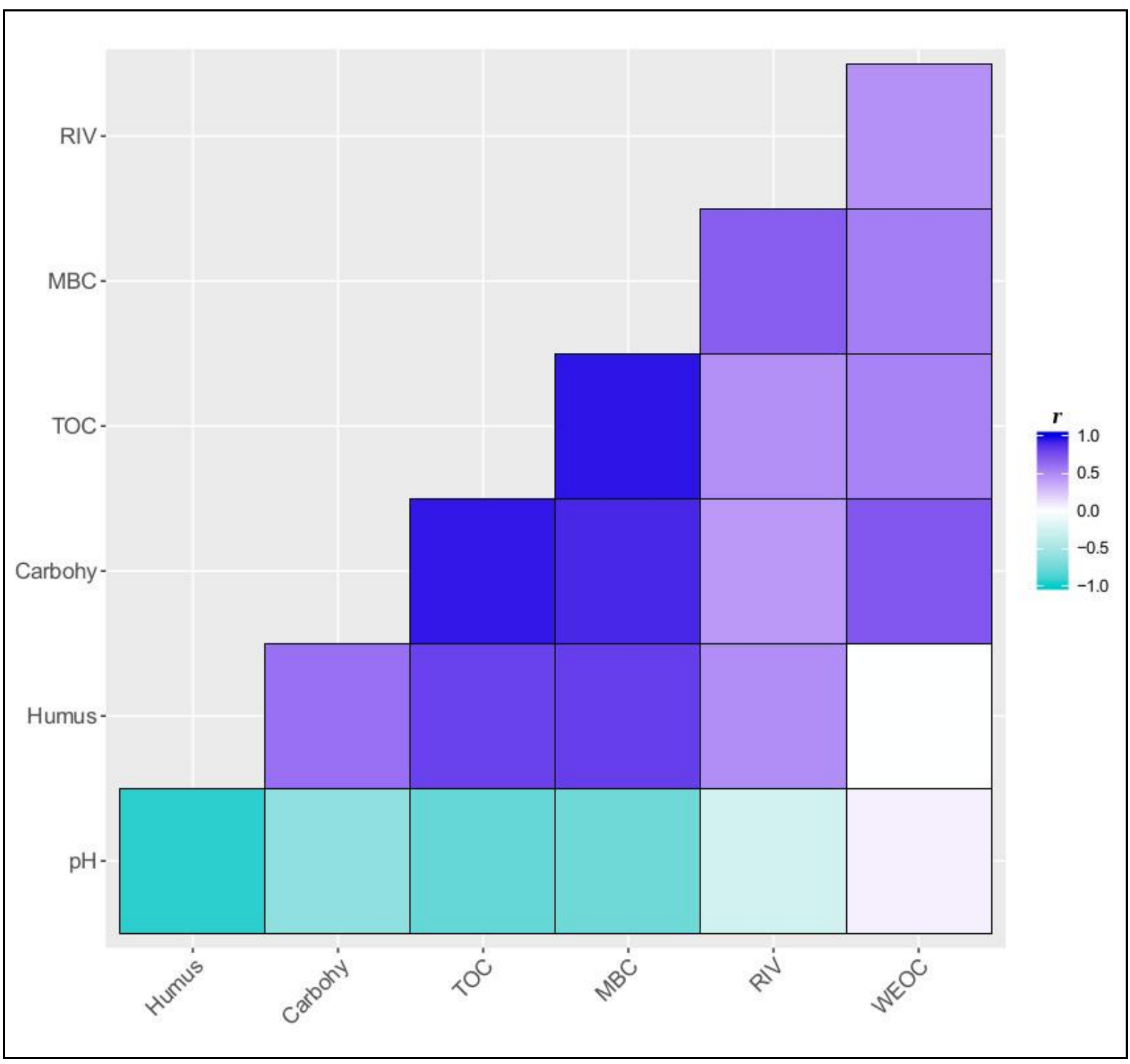


Supplementary Fig.1 Description and cropping history of the Soil sampling sites used for the study

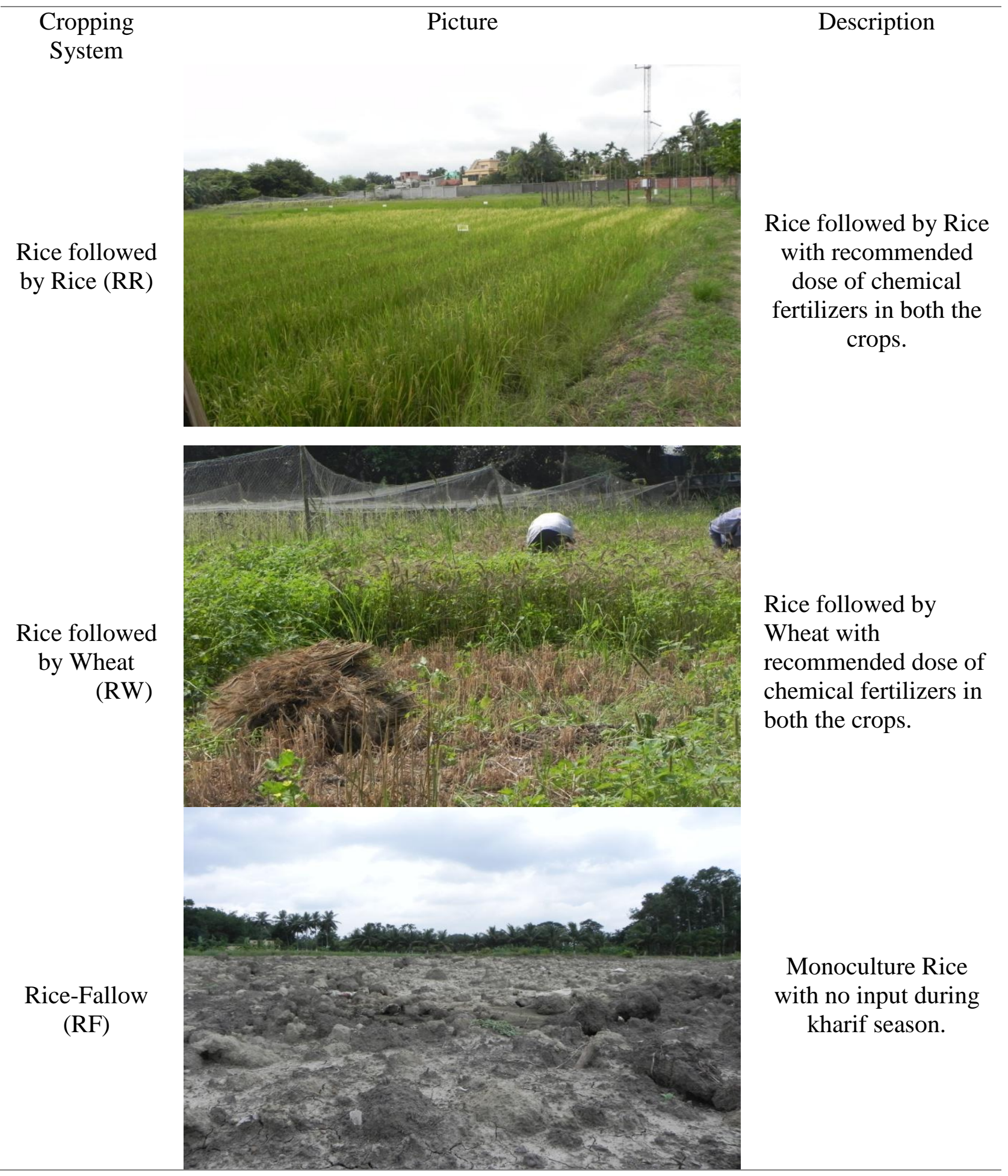




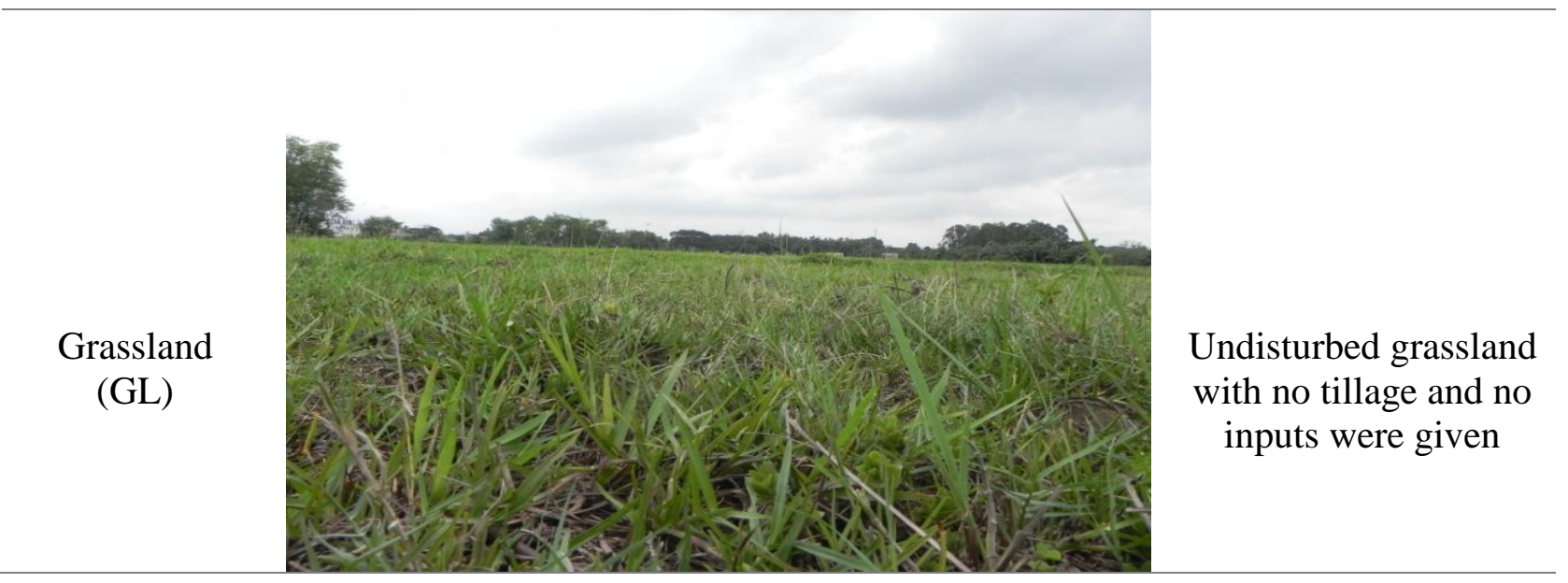

A closer look to the soil $\mathrm{C}$ fractions may reveal effect of land use pattern on the soil $\mathrm{C}$ dynamics pattern more clearly. This study suggests one of the most insidious effects of excess tillage is the loss of carbon bound in the soil in the form of humus. Humification being a continuous biochemical process produces several long chain organic polymers. Humus possesses several functional groups capable of attracting and dissociating $\mathrm{H}^{+}$ions (phenolic, amino etc.) hence producing acids. Humus also reacts with iron and aluminum ions to form complexes that may undergo subsequent hydrolysis to yield $\mathrm{H}^{+}$ions (Bear, 1964). The higher humus $\mathrm{C}$ of GL or RF may be attributed to lesser tillage effect and moreover the acidic nature of GL or RF may be also due to higher humus present in those soils. The negative correlation appeared between $\mathrm{p}^{\mathrm{H}}$ and humus $\mathrm{C}$ reflects the same fact. The CEC of any soil is the combined effect of the soil mineral and soil organic matter (Stevenson, 1994). Humus colloids exhibit very high levels of surface area and negative charge, Humus generally accounts for 50 to $90 \%$ of the cationabsorbing power of mineral surface soils (Brady and Weil, 2012). Thus, high humus content influencing the CEC in Grassland soil is evident from the results. The same reason of lowered humus $\mathrm{C}$ reflected lower CEC in RR soils. Carbon present within water extractable organic (WEOC) matter accounts for only a small portion of total organic matter in soil (McGill et al., 1986). Nevertheless, it is now recognized that these molecules influenced soil biological activity (Flessa et al., 2000). Numerous biotic and abiotic factors can control the dynamics of water extractable organic matter (Kalbitz et al., 2000). The differences in land use management controlling biological activities and biotic factors may have influenced the amount of WEOC. This might be related to rhizo-deposition of different crops, specific plant-microbe relationship etc. The higher amount of WEOC in rice-wheat system than rice-rice or rice-fallow suggests a better soil health with higher biotic reasons in rice-wheat cultivation. Ghani et al., (2003) also observed strong correlations of water soluble $\mathrm{C}$ with $\mathrm{MBC}$ and total carbohydrates, and proposed it to be a sensitive indicator to reflect dynamics of soil $\mathrm{C}$ dependent on management practices. In our observation, the correlation of WEOC, MBC and total carbohydrate depicts the same picture. Like WEOC, soil carbohydrates are also considered as a sensitive indicator of biotic status in soil. Carbohydrates supply carbon sources for microbial activities that contribute to mineral nutrient production in soil. The strong positive correlation of carbohydrate and MBC establishes this fact well. Carbohydrates also acts as building blocks in humus synthesis, the correlation of humus of carbohydrate content may be due to 
this reason. The higher amount of soil carbohydrate in RR and RW than RF may be attributed to higher plant deposition and carbohydrate accumulation. This in turn facilitated the microbial biomass $\mathrm{C}$ in $\mathrm{RR}$ and RW than in RF. Correlation study showed trend of microbial biomass carbon content of the soils was more or less similar with that of water extractable carbon as well as soil carbohydrate. These later two fractions of soil carbon are biogenic in nature. In general, it was clearly indicated that GL soil with higher organic carbon recorded higher microbial biomass carbon while RF soil with lowest organic carbon contains lowest microbial biomass. The proportion of microbial biomass carbon in soil organic carbon has been suggested as an index for monitoring soil development (Insam and Domsch, 1988) changes under different cropping system and land use (Insam et al., 1991) and soil degradation or recovery. The microbial biomass in soils comprises of a substantial pool of nutrients (Anderson and Domsch, 1980) which depending on the stage of growth, can be a source or sink of plant nutrients (Duxbury et al., 1989). A close relationship between microbial biomass and soil fertility indices has been noted earlier. The correlation of RIV with all the other parameters suggests its efficacy of depicting overall soil health. In our study, statistically significant highest RIV value in GL represents its virgin, undisturbed and biologically healthy status. All the four soils observed in these study are within the range of $1 \%-5 \%$ as reported previously (Smith and Paul, 1990). Microbial biomass is a labile pool of plant nutrient in soil. Among the cultivated soils studied here in, rice-wheat system seems to be the best in respect of labile pool of plant nutrient.

It is concluded that in the top soil, different pools of soil organic $\mathrm{C}$ were distributed in different manner and it was influenced by land cultivation. Intensive agricultural practices caused losses of soil C gradually over the years, which was evident from soil $\mathrm{C}$ status of cultivated soils as compare to that of uncultivated grassland soils. Differential cultivation practices and choice of crop may result in variation of soil $\mathrm{C}$ dynamics and status, even the quantity of net $\mathrm{C}$ stored in soil. Management practices like continuous tillage operations, in rice-rice field may have destroyed soil structures leading to higher $\mathrm{C}$ loss than that of rice-wheat system with conservation tillage. Most stable $\mathrm{C}$ pools like humus as well as labile pool like WEOC showed, how soil $\mathrm{C}$ status may be affected by tillage when compared between rice rice and rice wheat system. Microbial biomass, the most active pool of soil $\mathrm{C}$ was also facilitated in the practices of rice wheat. $\mathrm{MBC}$ and WEOC, these two parameters could be assayed as most sensitive towards land use management, as found in this study. Most of the soil $\mathrm{C}$ pools were positively and significantly correlated to each other with varying magnitude, and they had also constituted different proportion of TOC. Keeping the soil fallow for one season, may result in lower carbohydrate or microbial biomass but it helps for building up recalcitrant $\mathrm{C}$ pool like humus in higher amount than the practices where field is not kept fallow. The overall study emphasizes on few sensitive biochemical parameters for better understanding of soil condition as well as it reflects the goodness of crop rotation like rice-wheat over other cropping systems in terms of overall soil $\mathrm{C}$ health.

\section{Acknowledgement}

The authors are thankful to the director of Institute of Agricultural Sciences and head of the department, Agriculture Chemistry \&Soil Science, University of Calcutta for providing necessary fund and facilities. 
Abbreviations: TOC- Total Organic Carbon. TKN- Total Kjeldahl Nitrogen. MBCMicrobial Biomass Carbon. RIV- Ratio Index Value. CEC- Cation Exchange Capacity, SOC- Soil Organic Carbon.

\section{References}

Amato M and Ladd J N (1988), An assay for microbial biomass based on ninhydrinreactive nitrogen in extracts of fumigated soils. Soil BiolBiochem 20:107-114

Andersen JPE and Domsch KH (1980), Quantities of plant nutrients in the microbial biomass of selected soils. Soil Sci130 : 211-216

Bascomb C L (1964), Rapid method for the determination of cation- exchange capacity of calcareous and non- calcareous soils. J Sci Food Agric 15(12): 821-823

Bear F (1964), Chemistry of the soil. 2nd edn. Oxford and IBH publishing Co., India.

Becker M and Johnson D E (2001), Cropping intensity effects on upland rice yield and sustainability in West Africa, NutrCyclAgroecosys 59: 107-117

Bell J M, Smith J L, Bailey V L, Bolton H (2003). Priming effect and carbon storage in semi-arid no till, spring crop rotation. BiolFertil Soil 37: 237-244

Brady N C and Weil R R (2012). The Nature and Properties of Soils, 14th edition (revised). Pearson Education. New Delhi.

Duxbury J M, Scott M S, Doran J W, Jordan C, Szott L, Vance E (1989). Soil organic matter as a source and a sink of plant nutrients. In: Dynamics of Soil Organic Matter in Tropical Ecosystems, ed. Coleman DC, OadesJM ,Uehara G. University of Hawaii Press, Honolulu. pp. 33-67

Flessa H, Ludwig B, Merbach, W (2000). The origin of soil organic $\mathrm{C}$, dissolved organic $\mathrm{C}$ and respiration in a long term maize experiment in Halle, Germany, determined by $13 \mathrm{C}$ natural abundance. J. plant-Nutr. Soil Sci. 163: 157-163

Ghani A, Dexter M, Perrott K W (2003), Hotwater extractable carbon in soils: a sensitive measurement for determining impacts of fertilisation, grazing and cultivation. Soil BiolBiochem 35: 12311243

Haynes R J (2009) Labile organic matter fractions as central components of the quality of agricultural soils: an overview. AdvAgron 85:221-268

Huang Z, Xu Z, Chen C, Boyd S (2008) Changes in soil carbon during the establishment of a hardwood plantation in subtropical Australia. For Ecol Manage 254(1): 46-55

Insam H, Domsch K H (1988). Relationship between soil organic carbon and microbial biomass on chronosequence of reclaimed sites. MicrolEcol 15: 177188.

Insame H, Mitchell CC, Dormaar JF (1991), Relationship of soil microbial biomass and activity with fertilization practices and crop yield of three ultisols. Soil BiolBiochem 24: 459-464

Jenkinson D S(1994). Organic materials alive and dead. In: Soil Science Methods and Application; Rowell, D.L. (ed), Longman Scientific and Technical. UK: 38-41.

Kalbitz K, Solinger S, Park J H, Miahalzik B, Matzaer E (2000). Controls on dynamics of dissolved organic matter in soils: a review. Soil Sci. $165: 277-304$

Kononova, M (1966), Soil Organic Matter: Its Nature, Its Role In Soil Formation and In Soil Fertility. 2nd English Edition, Pargamom Press, Oxford, London.

Kumar K, Goh K M (1999) Crop Residues and Management Practices: Effects on Soil Quality, Soil Nitrogen Dynamics, Crop Yield, and Nitrogen Recovery. 
AdvAgron 68: 197-319

McGill W B, Cannon K R, Robertson J A, Cook, F D (1986). Dynamics of soil microbial biomass and water-soluble organic $\mathrm{C}$ in Breton $\mathrm{L}$ after 50 years of cropping to two rotations. Can J Soil Sci 66: 1-19.

Mitsuchi M (2012) Characters of humus formed under rice cultivation. Soil Sc Plant Nutr., 20(3): 249-259

Nieder R, Benbi D K (2008) Carbon and Nitrogen in the Terrestrial Environment. Springer Science \& Business Media

Šafař́k I and Šantrůčková H (1992). Direct determination of total soil carbohydrate content . J. Plant Soil, 143: 109-114

Shepherd T G, Saggar S, Newman R H, Ross C W, J. L. Dando (2001) Tillageinduced changes to soil structure and organic carbon fractions in New Zealand soils. Aust J Soil Res 39(3): $465-489$

Smith J L and Paul E A (1990), The significance of soil microbial biomass estimations. In: Soil Biochemistry, 6, pp: 357-396. Marcel Dekker. Inc., NY,
USA.

Sparling G P (1992), Ratio of microbial biomass carbon to soil organic carbon as a sensitive indicator of changes in soil organic matter. Aust J Soil Res 30(2): $195-207$

Stevenson FJ, (1982), Humus Chemistry; Genesis, Composition, Reactions, 2nd edition. John Wiley \& Sons, INC.

Vaccari F P, Lugato E, Gioli B, D'Acqui L, GenesioL, Toscano, P, Matese, A, Miglietta, F (2012). Land use change and soil organic carbon dynamics in Mediterranean agro-ecosystems: The case study of Pianosa Island. Geoderma 175-176: 29-36

Vance E D, Brookes P C, Jenkinson D S (1987). An extraction method for measuring soil microbial biomass $\mathrm{C}$. Soil Biol and Biochem 19: 703-707

Walkley A, Black I A (1934), An examination of the Degtjareff method for determining soil organic matter, and a proposed modification of the chromic acid titration method. Soil Sc 37(1): 3938.

\section{How to cite this article:}

Swayambhu Ghosh, Kalyan Chakrabarti, Aritra Kumar Mukherjee and Sudipta Tripathi. 2020. Different Rice based Cropping Systems can Influence Various Soil Organic Carbon Pools in a Clay Loam Soil of West Bengal. Int.J.Curr.Microbiol.App.Sci. 9(03): 1884-1897. doi: https://doi.org/10.20546/ijcmas.2020.903.219 